\title{
GRAPPLE SAW'S OPERATING CONDITIONS INFLUENCE ON THE PRODUCTIVITY AND COST OF PROCESSING FELLED TREES
}

\author{
Danilo Simões ${ }^{1}$, Lara Tatiane Avelino ${ }^{2}$, Rafaele Almeida Munis ${ }^{2 *}$, Gislaine Cristina Batistela ${ }^{3}$, Ricardo Hideaki \\ Miyajima $^{2}$

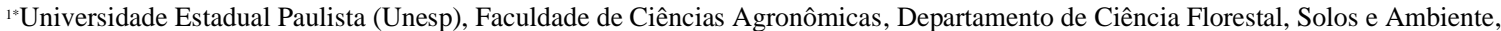 \\ Botucatu, São Paulo, Brazil - danilo.simoes@unesp.br \\ ${ }^{2}$ Universidade Estadual Paulista (Unesp), Faculdade de Ciências Agronômicas, Programa de Pós-Graduação em Ciência Florestal, Botucatu, \\ São Paulo, Brazil - laratatianeavelino@gmail.com; *rafaele.munis@gmail.com; richidetoshimiyajima@hotmail.com \\ ${ }^{3}$ Universidade Estadual Paulista (Unesp), Câmpus Experimental de Itapeva, Coordenadoria de Curso de Engenharia de Produção, Itapeva, \\ São Paulo, Brazil - gislaine.batistela@unesp.br \\ Received for publication: 29/07/2020 - Accepted for publication: 26/08/2021
}

\section{Resumo}

Influência das condições operacionais da grapple saw na produtividade e custos do processamento de árvores derrubadas. No sistema full-tree uma das máquinas florestais autopropelidas empregadas é a grapple saw que por meio de força mecânica realiza o desgalhamento e corte dos fustes, comumente em pátios de processamentos ou às margens das estradas florestais. Deste modo, diversos fatores podem influenciar a produtividade efetiva da máquina, e consequentemente os custos de produção. Assim, objetivou-se analisar a influência da declividade do terreno na produtividade e nos custos de produção da grapple saw em condições operacionais distintas. O estudo foi desenvolvido em uma área florestal, na qual havia florestas clonais de Eucalyptus urograndis. A operação de processamento das árvores derrubadas foi realizada com uma grapple saw com capacidade de acúmulo para feixes de árvores de $0,85 \mathrm{~m}^{2} \mathrm{em}$ duas condições operacionais. Para a previsão da produção aplicou-se o estudo de tempos, associando-o ao volume de madeira traçada e o tempo efetivo de trabalho, por conseguinte, foi possível estimar o custo de produção da grapple saw. Os resultados permitiram concluir que a produtividade efetiva da máquina e o custo de produção do traçamento das toras estão associados à declividade do terreno.

Palavras-chave: Colheita de madeira, declividade do terreno, estudo de tempos, planejamento florestal, análise econômica.
\end{abstract}

\begin{abstract}
In the full-tree system, one of the self-propelled forest machines used is the grapple saw, which uses mechanical force to delimbing and crosscutting stems, commonly in processing yards or on the sides of forest roads. Thus, several factors can influence the machine's effective productivity, and consequently, the production costs. Hence, the objective was to analyze the influence of the slope of the land on the productivity and production costs of the grapple saw under different operational conditions. The study was carried out in a forested area, in which there were clonal forests of Eucalyptus urograndis. The processing felled trees operation was performed with a grapple saw capable of accumulating and cutting the $0.85 \mathrm{~m}^{2}$ tree bundles in two operating conditions. For the production forecast, the time study was applied, associating it to the volume of drawn wood and the effective work time, accordingly, it was possible to estimate the production cost of the grapple saw. The results allowed to conclude that the effective hourly productivity and the production cost of the log tracing are associated with the slope of the land.
\end{abstract}

Keywords: Timber harvesting, land slope, time studies, forest planning, economic analysis.

\section{INTRODUCTION}

The harvesting of mechanized wood is carried out by means of self-propelled machines and machines composed with mechanisms that allow the felling of trees, the processing felled trees and, sometimes, the debarking of the wood, as soon, characterized as self-propelled forest machines. That said, when weighing the financial contribution for the acquisition of these machines and mainly of the variable costs, analyzes must frequently be carried out to optimize this productive resource.

In view of this, Spinelli et al. (2009), complement that the advance of technical and operational aspects must be in synergy with this mechanization process, wich, according to Blagojevic et al. (2019) will assist in decision making. Among the mechanized wood harvesting systems, the full-tree system, has the characteristic of removing the entire trees from the interior of the stand to an intermediate yard or to the edges of the forest roads. Subsequently, one of the operations is the processing felled trees, commonly made possible by the self-propelled grapple saw forest machine.

According to Spinelli et al. (2014) this self-propelled forest machine has a cabin with a 360 degree rotation, usually with track-type wheelsets, which has the purpose of tracing logs in pre-established sizes according to the specificity of the forest de limitations. In such manner, the information on productivity per effective hour and costs 
demand plausible results with a view to strategic planning of operations, as a support for decision making of forest operations (HIESL; BENJAMIN, 2013).

Thus, the knowledge of the effective hourly productivity of self-propelled forest machines allows the dimensioning of mechanized forest operations (SCHETTINO et al., 2015), as according to Nascimento et al. (2011) the machines choice is determined based on information of the facts that influences both technical and economic element.

Among the factors that most influence productive machine hour $(\mathrm{PMH})$ and, as consequence, the production costs of grapple saw, the forest productivity, diameter at breast-height (DBH), number of trees, individual average volume (IAV) and the log tracing time stand out (FIEDLER et al., 2008). In addition to these, terrain conditions must also be considered, which includes the slope, terrain configuration and the carrying capacity (ALAM et al., 2014). Thereat, the analysis of operational conditions is one of the premises for minimizing the cost per volume produced (CARMO et al., 2015).

In this context, it is hypothesized that the slope of the land may influence the productivity of the grapple saw during the processing felled trees of Eucalyptus urograndis. Hence, the objective was to analyze the influence of land slope on grapple saw productivity and production costs under different operating conditions.

\section{MATERIAL AND METHODS}

\section{Study area}

The study was carried out in a clonal forest with Eucalyptus urograndis located at the geographical coordinates $23^{\circ} 10^{\prime}$ in South Latitude and $48^{\circ} 19^{\prime}$ in West Longitude, in the state of São Paulo, Brazil. At the time of harvesting, the forest in first rotation planted at $3 \mathrm{~m} \times 2 \mathrm{~m}$ spacing, was 72 months old and had trees with an average height of $25 \mathrm{~m}$, average diameter at breast-height $(\mathrm{DBH})$ of $14.9 \mathrm{~cm}$ and the average individual tree volume was $0.20 \mathrm{~m}^{3}$. The purpose of this forest was to supply wood to a forest-based industry that produced wood fiber panels and particulate wood panels.

According to the Köppen-Geiger classification, the climatic characteristics of the region were characterized as wet temperate $\mathrm{Cwa}$, with dry winter and hot summer, with an average annual temperature of $21.5^{\circ} \mathrm{C}$ and $1,490.6$ $\mathrm{mm}$ of average annual precipitation (CEPAGRI, 2019). As for the soil units in the region, these were classified as a typical Neosol Quartzarenic Ortico, A moderate, alic, sandy texture, with classes of slopes of the land where the forest operation was carried out, characterized as undulating, or better, with a slope of $8.0 \%$ to $20.0 \%$ as described by Santos et al. (2018).

\section{Technical analysis}

The processing felled trees operation was carried out by means of a self-propelled forest machine characterized grapple saw, Caterpillar brand, model 320 D FM (Figure 1), with $117 \mathrm{~kW}$ of net motor power at nominal rotation, with a loading boom with $9.1 \mathrm{~m}$ in length, operating mass of $26,900 \mathrm{Kg}$, with 13,114 hours of accumulated use and wheelset system composed of tracks.

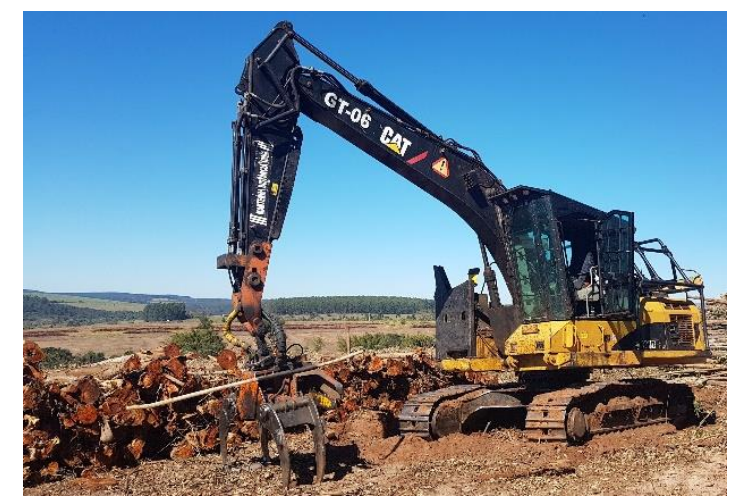

Figure 1. Self-propelled forestry machine grapple saw.

Figura 1. Máquina florestal autopropelida grapple saw.

At the end of this loading boom, a grapple saw of the J de Souza brand, model TJPG, for the to log processing, was attached, with it had the capacity of accumulation and cutting tree bundles of $0.85 \mathrm{~m}^{2}$, realized by a 60 inch saw bar. The processing consisted of the movements of the tree bundles in the longitudinal direction to perform the delimbing, being the crosscutting of the stem with approximately $7.20 \mathrm{~m}$ in length, and finally, the formation of the stacks with logs for later loading. 
In this perspective, two operational conditions were evaluated, pondering, a single operator with five years of experience with grapple saw, performed the processing uphill and downhill of the land, e.g: Operational condition $1(\mathrm{C} 1)$ tree bundles were arranged together on the edges of forest roads, in the direction of the slope of the land (uphill), with a slope of $11.9 \%$; Operational condition $2(\mathrm{C} 2)$ the tree bundles were arranged on the edges of the forest roads, in the direction of the land slope (donwhill), with a slope of $12.0 \%$.

The data were collected at the same hours and climatic conditions, that is, during the work shift from 7 am to $3 \mathrm{pm}$, with sunshine throughout the study period, i.e., without the occurrence of rainfall. Thus, with a view to forecasting and planning the production, the study of times was applied by means of a manual digital stopwatch, considering the precision of one second and without stopping the time.

Then, to calculate the minimum number of work cycles (Equation 1), 100 work cycles were observed for a preliminary estimate of the sample size, considering the average times of the machine elements and the standard deviation of the sample with a degree of precision of $95.0 \%$ and error of $5.0 \%$.

$$
n=\left(\frac{Z S}{E}\right)^{2}
$$

In which:

$n$ is the sample size;

$z$ is the value of the Standard Normal distribution with the desired confidence level (tabulated);

$S$ is the standard deviation of the pilot sample;

$E$ is the desired margin of error.

The machine elements (ME), that is, elements performed by the grapple saw operator during the work cycle were: picking up tree bundles (ME1); crane loaded movement (ME2); crane empty movement (ME3); and processing (ME4). Considering the details of the working methods, and associated with the measurement of the relative quantities, it was possible to estimate the machine productivity, given through the relationship between the volume the volume of processing and the productive work time (Equation 2).

$$
E M P=\frac{V O L}{\sum_{M E=1}^{4} \frac{P W_{M E}}{3600}}
$$

In which:

$E M P$ is the effective machine productivity $\left(\mathrm{m}^{3} \mathrm{~h}^{-1}\right)$;

$M E$ is the machine elements;

$V O L$ is the volume of cutting wood $\left(\mathrm{m}^{3} \mathrm{~h}^{-1}\right)$;

$P W_{M E}$ is the productive work time of each machine elements, for $M E=1,2,3$ e 4 (s).

The energy consumption that allows inferring about the energy efficiency, was estimated from the ratio between the specific fuel consumption in grams for each kilowatt delivered during one hour and the effective machine productivity (Equation 3). Thus, the calculation of effective specific consumption (CSE) was obtained in line with the methodology proposed by the United Nations Economic Commission for Europe (2007).

$$
E \gamma=\frac{C S E}{E M P}
$$

In which:

$E \gamma$ is the energy efficiency $\left(\mathrm{g} \mathrm{kW}^{-1} \mathrm{~m}^{3}\right)$;

CSE is the effective specific consumption $\left(\mathrm{g} \mathrm{kW}^{-1} \mathrm{~h}^{-1}\right)$.

\section{Statistical design}

In order to employ the appropriate statistical treatment of the data, the assumptions of normality of the data and homogeneity of the variances were first verified by applying the Kolmogorov-Smirnov and Bartlett tests at the 5\% significance level and opting for non-parametric tests, that is, free distribution tests. The productivity, machine production cost (MPC) and energy efficiency were subjected to the median comparison test, Wilcoxon Rank Sum Test, in order to establish whether there was a statistical difference under the two different operational conditions of the grapple saw (C1 and $\mathrm{C} 2)$.

In addition, a post hoc analysis of the medians of the time spent for each element of the work cycle was applied, using the non-parametric test in Friedman blocks, at the 5.0\% significance level, in order to identify the impact of each element at the time of grapple saw productivity, taking into account the different operating conditions. 
Finally, through Spearman's rank $\left(\rho_{s}\right)$ correlation, at a significance level of $5.0 \%$, the occurrence of monotonous relationships between the machine elements of the work cycle was determined, that is, the intensity of the interactions between the operational elements was verified. Thus, statistical analyzes were performed using R software version 3.5.2 (R DEVELOPMENT CORE TEAM, 2019).

\section{Economic analysis}

Monetary values were expressed in US Dollars (USD), in view of this, the exchange rate expressed in national currency was adopted, in the Brazilian Real (BRL), which was BRL 4.1385, according to information made available on December 30. August 2019 by the Central Bank of Brazil (2019).

The machine costs per hour scheduled $(\mathrm{MCH})$ was based the expected economic life of grapple saw, i.e., in scheduled machine hour (SMH) according to assumptions and hourly rates (Table 1). Was adopted the methodology proposed by Ackerman et al. (2014), which included the fixed costs of depreciation, interest on average annual investment, insurance, machine tax and garaging for machine. Regarding variable costs, monetary values spent on fuel, oil and lubrications, maintenance and repair, tracks, cutting chain, chain saw, operator costs which included varying social charges and other operator benefits were considered.

Table 1. Cost assumptions and hourly rates.

Tabela 1. Pressupostos de custo e taxas horárias.

\begin{tabular}{llr}
\hline \multicolumn{1}{c}{ Factor } & Unit. & Value \\
\hline Investment price & USD & 247,628 \\
Salvage value & USD & 49,525 \\
Fuel consumption & $\mathrm{L} \mathrm{h}^{-1}$ & 27.83 \\
Diesel price & $\mathrm{L}$ & 1.03 \\
Power & $\mathrm{kW}$ & 117 \\
Economic life & $\mathrm{h}$ & 30,000 \\
Number of working days per year & $\mathrm{d}$ & 283 \\
Number of shifts per day & $\mathrm{d}$ & 3 \\
Scheduled hours per shift & $\mathrm{h}$ & 8 \\
Machine utilization & $\%$ & 78.0 \\
Estimated track set life & $\mathrm{h}$ & 5,000 \\
Saw bar & $\mathrm{h}$ & 5,000 \\
Saw bar chain & $\mathrm{h}$ & 500 \\
Operator basic wage & $\mathrm{USD} \mathrm{h}$ & 13.93 \\
Social charges & $\%$ & 134.0 \\
Operator benefits and overheads & $\%$ & 10.0 \\
Overhead & $\%$ & 5.0
\end{tabular}

As for the rate to estimate interest on investment (Equation 4), the Weighted Average Cost of Capital (WACC) was adopted because the company that owns the grapple saw has the participation of creditors' capital.

$$
W A C C=(1-\mathrm{T}) C_{c} \frac{k_{c}}{k_{s}+k_{c}}+C_{s} \frac{k_{s}}{k_{s}+k_{c}}
$$

In which:

$C_{c}$ is the capital cost of creditors;

$C_{s}$ is the capital cost of shareholders;

$k_{c}$ is the participation of the creditors' capital;

$k_{s}$ is the participation of the shareholders' capital;

$k_{c}$ is the participation of the creditors' capital;

$(1-\mathrm{T})$ is the adjustment factor for expenses with tax-deductible interest, so $\mathrm{T}$ represents the Corporate Tax

Rate and the Net Income Contribution. 
That said, it was fundamentally necessary to calculate the rate estimate (Equation 5) of the cost of equity capital obtained through the Capital Asset Pricing Model (CAPM).

In which:

$$
C_{s}=R_{f}+\beta\left(R_{e}-R_{f}\right)+\kappa_{c r}
$$

$R_{f}$ is the risk-free rate;

$\beta$ is the systematic re-leveraged coefficient of the forestry sector;

$R_{e}$ is the return expected by the forestry market;

$\left(R_{e}-R_{f}\right)$ is the premium for the forest market risk;

$\kappa_{c r}$ is the country-risk premium.

The production cost per unit of output (PCU) denoted by USD per $\mathrm{m}^{-3}$ was estimated from the ratio between the machine costs per hour scheduled and the effective machine productivity.

\section{RESULTS}

\section{Analysis of technical parameters}

As for the sample size, 272 work cycles were observed, allowing a desired margin of error of $4.4 \%$ for the assessment of the working methods observed during the total effective time of the operation of 10 hours and 8 minutes, which provided the processing of $1,169 \mathrm{~m}^{3}$ of wood.

When analyzing the work cycles elements on both operational conditions, it was verified that the ME2 of $\mathrm{C} 1$ and all $\mathrm{ME}$ of $\mathrm{C} 2$ had normal distribution using the Kolmogorov-Smirnov test. Nevertheless, the assumption of homoscedasticity obtained using Bartlett test was only accepted equating the ME3, effective time, volume and productivity in both operational conditions under analysis.

In view of this, Spearman's rank correlation was obtained, through which the intensity of the interactions of the factors was verified, for the operational condition $\mathrm{C} 1$ (Figure 2A) and for the operational condition $\mathrm{C} 2$ (Figure 2B).

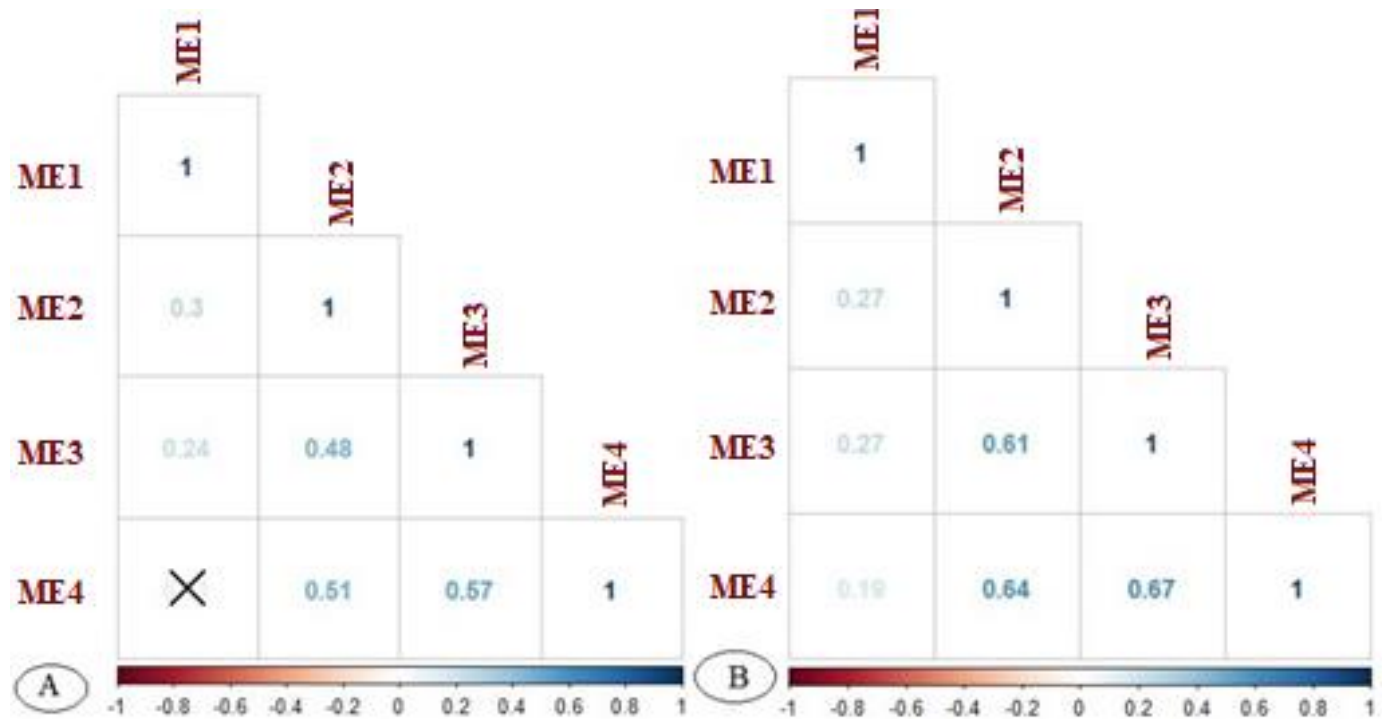

Figure 2. A - Spearman's rank correlation for the operational condition C1; B - Spearman's rank correlation for the operational condition $\mathrm{C} 2$; $\mathrm{X}$ represents no correlation.

Figura 2. A - Classificação da correlação de Spearman, para a condição operacional C1; B-- Classificação da correlação de para a condição operacional $\mathrm{C} 2$; X representa correlação não significativa.

The impact of each machine element on the total effective time was investigated and, then, the productivity of the grapple saw hour in operating conditions $\mathrm{C} 1$ and $\mathrm{C} 2$. It was observed that in the operational condition $\mathrm{C} 1$, there was no statistical difference between these elements (Figure 3A). Conversely, in operational condition C2, machine elements ME2 and ME4 differed statistically from each other (Figure 3B). 


\section{Groups and Range}

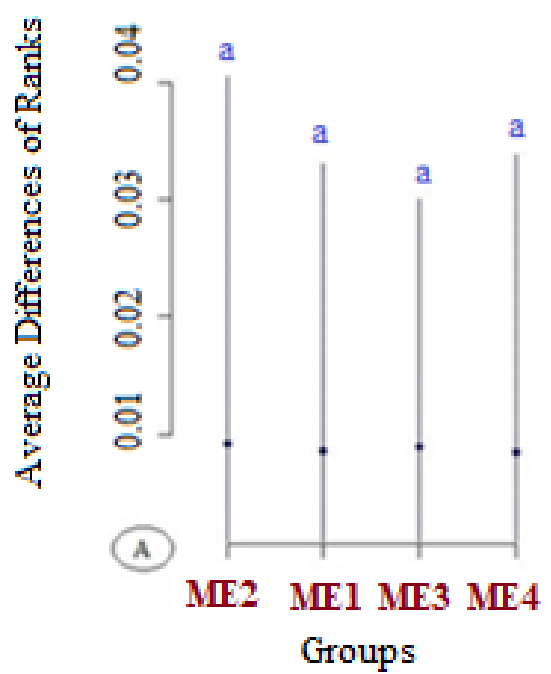

\section{Groups and Range}

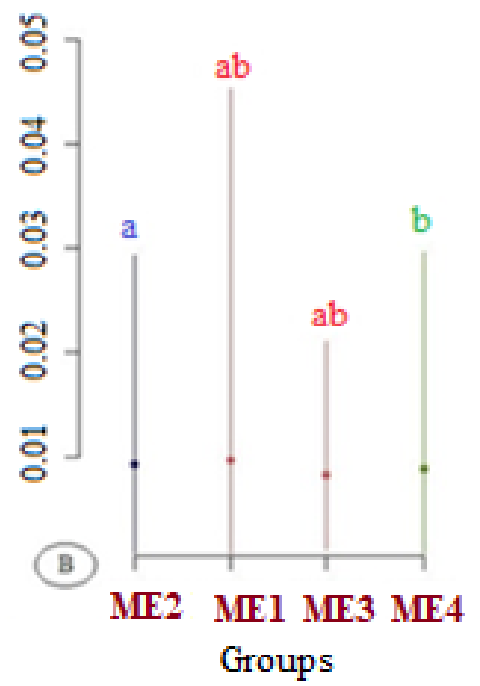

Figure 3. A - Machine elements post hoc in operational condition $\mathrm{C} 1$; B - Machine elements post hoc in operational condition $\mathrm{C} 2$.

Figura 3. A - Post hoc dos elementos de máquina na condição operacional C1; B - Post hoc dos elementos de máquina na condição operacional C2.

From the systematic analysis of the consumption of working times required for the log processing of Eucalyptus urograndis, it was possible to establish a comparison of the effective machine productivity of the grapple saw in the two operational conditions, that is, in operational condition $\mathrm{C} 1$ the productivity per minimum effective hour was $29.36 \mathrm{~m}^{3} \mathrm{~h}^{-1}$ with a maximum $210.99 \mathrm{~m}^{3} \mathrm{~h}^{-1}$, and in operational condition $\mathrm{C} 2$ the minimum effective machine productivity was $38.94 \mathrm{~m}^{3} \mathrm{~h}^{-1}$ and the maximum $242.87 \mathrm{~m}^{3} \mathrm{~h}^{-1}$. In view of this, through the Wilcoxon Rank Sum Test non-parametric test, p-value of $4.34 \times 10-06$, he attested that there is a statistical difference in productivity per effective hour of work at the level of $5.0 \%$ of significance.

The median effective machine productivity of operating condition $\mathrm{C} 2$ was $24.8 \%$ higher than the median of effective machine productivity estimated for operating condition $\mathrm{C} 1$. Thus, when considering the average specific fuel consumption of $198.85 \mathrm{~g} \mathrm{~kW}^{-1} \mathrm{~h}^{-1}$, the median energy efficiency for operational condition $\mathrm{C} 2$ was $19.8 \%$ lower than the median estimated energy efficiency for operating condition C1 (Table 2).

Table 2. Descriptive analysis of the processing felled trees parameters.

Tabela 2. Análise descritiva dos parâmetros do processamento de árvores derrubadas.

\begin{tabular}{|c|c|c|c|c|c|}
\hline Operational condition & Parameters & $\begin{array}{c}\text { Normality } \\
{[p \text {-value }]}\end{array}$ & Min. & Max. & Med. \\
\hline \multirow{4}{*}{$\mathrm{C}$} & Productive work time $\left[\mathrm{s} \mathrm{cycle}^{-1}\right]$ & $0.00 *$ & 54.00 & 281.16 & 113.58 \\
\hline & Volume of cutting wood $\left[\mathrm{m}^{3} \mathrm{cycle}^{-1}\right]$ & 0.21 & 0.79 & 8.11 & 3.66 \\
\hline & Effective machine productivity $\left[\mathrm{m}^{3} \mathrm{~h}^{-1}\right]$ & $0.00 *$ & 29.36 & 210.99 & $109.39 \mathrm{a}$ \\
\hline & Energy efficiency $\left[\mathrm{g} \mathrm{kW}^{-1} \mathrm{~m}^{-3}\right]$ & $0.00^{*}$ & 0.94 & 6.77 & $1.82 \mathrm{~A}$ \\
\hline \multirow{4}{*}{$\mathrm{C} 2$} & Productive work time $\left[\mathrm{s} \mathrm{cycle}^{-1}\right]$ & $0.01 *$ & 51,84 & 333.00 & 124.92 \\
\hline & Volume of cutting wood $\left[\mathrm{m}^{3}\right.$ cycle $\left.^{-1}\right]$ & 0.05 & 1,59 & 8.53 & 4.96 \\
\hline & Effective machine productivity $\left[\mathrm{m}^{3} \mathrm{~h}^{-1}\right]$ & 0.84 & 38,94 & 242.87 & $136.52 b$ \\
\hline & Energy efficiency $\left[\mathrm{g} \mathrm{kW}^{-1} \mathrm{~m}^{-3}\right]$ & $0.00 *$ & 0,82 & 5.11 & $1.46 \mathrm{~B}$ \\
\hline
\end{tabular}

Medians followed by the same letter, lower case, in the column, do not differ statistically at 5\% significance by the Wilcoxon test. Medians followed by the same letter, uppercase, in the column, do not differ statistically at $5 \%$ significance by the Wilcoxon test.* This is a lower bound of the true significance; C1 - Operational Condition 1; C2 - Operational Condition 2. 


\section{Costs estimation}

Due to the financial contribution demanded, the estimate of the discount rate to remunerate the capital applied to the acquisition of a self-propelled forest machine is a premise of paramount importance to be considered in the calculation of the machine costs per hour scheduled. So, the adoption of methods is justified that take into account the non-diversifiable risk to which shareholders are exposed and concatenated to the creditors' remuneration requirements, provided through the weighted average cost of capital (WACC).

The interest on average annual investment adjusted to the risk of the forestry market had the proposition of determining the cost of capital of shareholders based on the CAPM. Thus, the risk-free rate of 5.4\% estimated based on the geometric average of the Annual Return on Treasury bonds 10Y was adopted according to data provided by the United States Department of the Treasury from the year 1962 to the year 2020.

Still, the systematic risk coefficient of the forestry market, estimated based on the re-leveraged beta of the wood and cellulose sector taking into account the publicly traded companies that had shares traded in B3 SA Brasil, Bolsa, Balcão (2019), which were Duratex, Eucatex, Klabin and Suzano, which resulted in the average unlevered systematic coefficient of 0.33 , which when added to the debt of the company that owns the grapple saw, returned the company's leveraged beta of 0.42 .

As a market risk premium, the S\&P Global Timber \& Forestry index was assumed, provided by the company S\&P Dow Jones for a period of 10 years, resulting in an average annualized market return of 5.4\%. As for the risk-free rate, i.e., the Brazil risk premium resulting from the geometric average of debt securities issued by emerging countries since 1994 , was $4.0 \%$. Hence, for the creditors' accuracy, the required return was due to the $2.5 \%$ spread due to customer default, since Brazil had, in the period of the study, the speculative credit rating (BA2), thus, added to the free rate risk.

Finally, when considering the Corporate Income Tax rate of $25.0 \%$ and the Contribution on Net Income rate of $9.0 \%$, according to the taxation in force in the country on the capital participation of creditors of $42.9 \%$, the interest on average annual investment demanded to remunerate the capital applied for the acquisition of grapple saw was $7.6 \%$.

When analyzing the cost scheduled of the grapple saw, the value of 110.32 USD per hour was estimated. Among the cost components (Figure 4), operator costs represented $38.0 \%$, followed by fuel costs with $25.9 \%$ and maintenance and repair $9.0 \%$, that is, they represented $72.9 \%$ of cost scheduled per hour of the grapple saw.

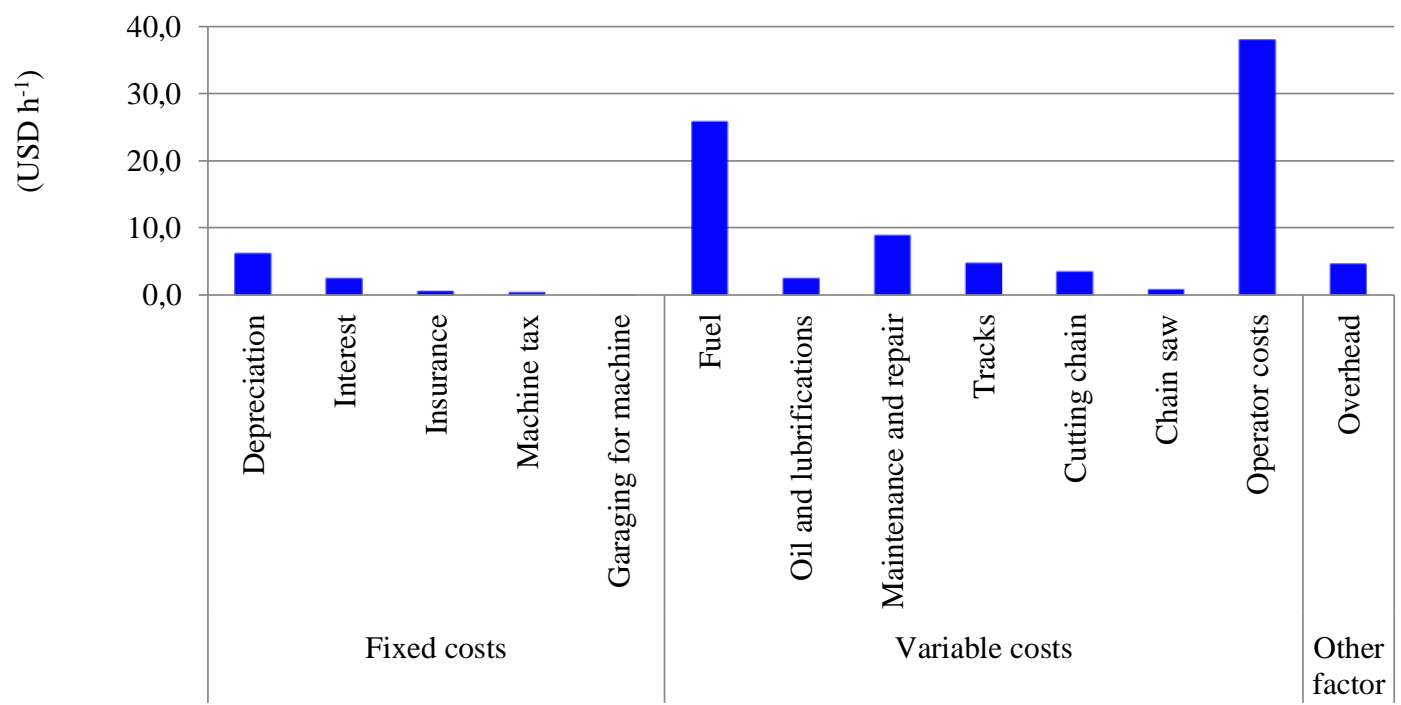

Figure 4. Cost per scheduled machine hour.

Figura 4. Custo por hora programada.

Regarding the production costs of the grapple saw, statistical differences were found corroborated through the Wilcoxon Rank Sum Test, p-value of $4.53 \times 10^{-06}$ (Figure 5) so that the median production cost for the operational condition C2 was USD $0.81 \mathrm{~m}^{-3}$, lower than the median estimated production cost for operating condition $\mathrm{C} 1$, which was USD $1.01 \mathrm{~m}^{-3}$. 


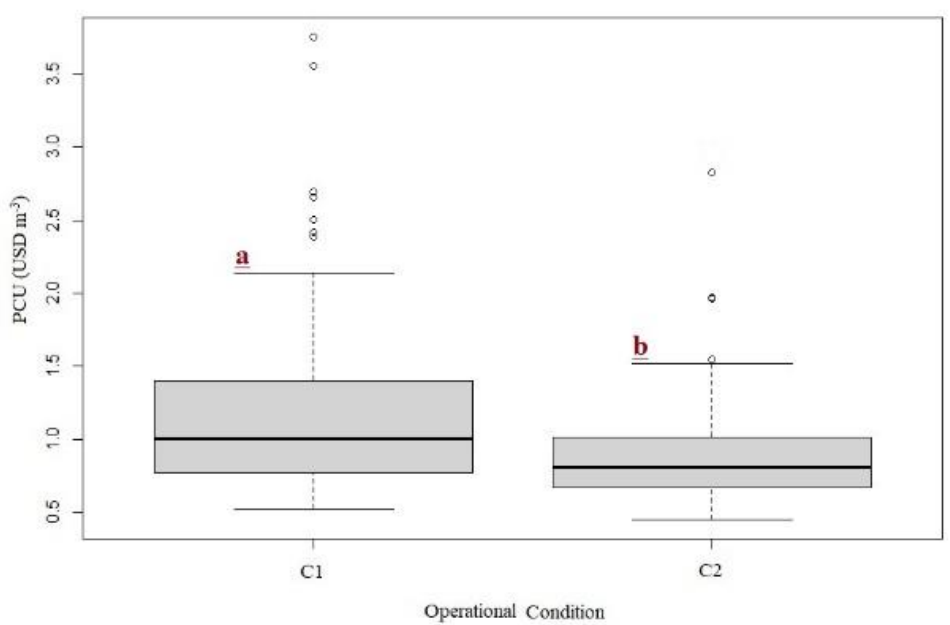

Figure 5. Boxplot cost of production under two operational conditions.

Figura 5. Boxplot dos custos de produção em duas condições operacionais.

\section{DISCUSSION}

The study of times is valuable for determining the productivity of self-propelled forest machines (BEHJOU et al., 2008). However, the reliability of the results is based on the sampling sufficiency that aims to certify whether the number of work cycles was sufficient to evidence the ideal size of the observations, the working methods, and, furthermore, whether the time spent for data collection was considered adequate. Then, based on the data series of effective working times for both operating conditions analyzed, the level of precision was reduced by $0.6 \%$ of the error initially stipulated, increasing the sampling reliability.

In this way, the average cycle time revealed for $\mathrm{C} 1$ was influenced by the time spent with crane movements, $29.1 \%$ for ME2 and $33.5 \%$ for ME3, that is, $62.6 \%$ of the time total cycle. Analogous condition evidenced for C2, represented mainly by $34.2 \%$ and $33.8 \%$, respectively, for ME 2 and ME3, which demanded $68.0 \%$ of the total average cycle time with the movement of the crane. These two machine elements are the ones that most intervened in the productive of the grapple saw hour, corroborating a previous study by Rocha et al. (2009).

Herewith, when analyzing the machine elements in operational condition $\mathrm{C} 1$, it was possible to observe that the variability in the data due to the difficulty of carrying out the operation, significantly affected the assumption of normality of the data, i.e., of the time spent for the final operation. However, in discussion of the operational condition $\mathrm{C} 2$ it was found that only the ME2 times assumed the normal probability distribution ( $p$ value of 0.1 , which can be explained due to the positioning of grapple saw usually adopted by the operator, corroborating that this machine element has a standard time for the processing, wich, according to Strandgard $e t$ al. (2013) the data were free of time variability.

It was found that the grapple saw during the operation in the slope direction of the terrain $(\mathrm{C} 2)$ required $5.1 \%$ more of the average effective time when compared to the average effective time of the processing with the grapple saw in the uphill direction of the terrain (C1). This finding corroborates the importance of applying the time study, which according to Bilici et al. (2018) allows forest managers to help plan and optimize mechanized wood harvesting operations.

Furthermore, the perception of the factors that inferred in the definition of the operational cycle of the log processing operation, through the technique of time study, facilitated and increased the accuracy when verifying the presence of interactions between the independent factors with the explanatory. In this perspective, when weighing which machine elements are correlated with each other, it was found through the modeling of Spearman's nonlinear correlation indicators for $\mathrm{C} 1$, that only ME1 presented a low, positive coefficient, that is, below 0.30 , according to association values demonstrated by Miot (2018). However, it is noteworthy that only ME1 was not significant with ME4.

Likewise, for the $\mathrm{C} 2$ operational condition, a weak positive correlation $\left(\rho_{s}<0.27\right)$ was observed between the ME1 and the other machine elements. Attention and sensitivity to the correlation values were necessary, so, based on the level of statistical significance, to provide subsidies for decision making, which based on explanatory factors, in addition to being essential, as recommended by Diodato and Bellocchi (2020) for forestry operations, contributed to improving the adjustment of factors intrinsic to the log processing operation of Eucalyptus urograndis. 
As for effective machine productivity, a difference of $24.8 \%$ between operational conditions was evidenced, therefore, for operational condition C2 the operator of the grapple saw had in his favor a favorable technical condition, that is, the formation of larger bundles of trees was possible, consequently, there were greater accumulations in the grapple saw, when compared to operational condition $\mathrm{C} 1$, validated by the difference in the average number of shafts per work cycle, respectively, 19 and 24, for operational condition $\mathrm{C} 1$ and $\mathrm{C} 2$. As observed, the higher the percentage of slope of the land, the smaller the volume of wood drawn, thus, the lower the effective machine productivity of the grapple saw.

As a way of predicting the factor that caused the greatest interference in the effective machine productivity of the grapple saw, through the post hoc test, it was evidenced that in the operational condition $\mathrm{C} 1$, there were no statistical differences between the execution times of the machine elements, or that is, the degree of feasibility of operations required the operator the same amount of time.

However, due to the operational condition $\mathrm{C} 2$ being in counterpoint to the ease of execution of operations ME2 and ME4, it was observed that ME2 presented a median of 42.48s, that is, it was above the median of 16.92s of ME4. This reflects that, the log processing was better in the operational condition $\mathrm{C} 2$, when compared to the crane loaded movement, this being the main factor of the variation of productivity per effective hour in this condition. Although the operation of self-propelled forest machines on a slope is more comfortable and productive, according to Alam et al. (2013), the crane loaded movement is added to the force of gravity, which acts in the opposite direction to displacement, thus making it difficult to perform these movements.

Regarding energy efficiency, it was possible to verify that among the two operational conditions, C1 presented an average energy efficiency of $2.067 \mathrm{~g} \mathrm{~kW}^{-1} \mathrm{~m}^{-3}$, higher than the $1.609 \mathrm{~g} \mathrm{~kW}^{-1} \mathrm{~m}^{-3}$ obtained in operational condition $\mathrm{C} 2$. It was corroborated that the energy efficiency and the productivity presented the behavior of inversely proportional quantities, that is, the operational condition that presented the highest productivity (C2). Thus, the higher the productivity of the self-propelled forest machine, the better the energy efficiency of the forest operation, that is, there was an optimization of the factors employed, a fact that can also be seen for the slope of the land.

The cost per hour scheduled was $126.7 \%$ higher than that calculated by Lopes et al. (2008) and 18.2\% lower than the values estimated by Magagnotti et al. (2013) for operations with grapple saw. These differences can be attributed to the methodologies adopted, or rather, to the weighted cost components, as an example, the consideration of the amounts spent with the saw bar, saw bar chain, overhead, among the analyzed components, and above all, to the operator costs related to the social charges, operator benefits and overheads totaling $144.0 \%$ of the cost associated with the operator.

Finally, cost of production of the grapple saw under operating conditions $\mathrm{C} 1$ and $\mathrm{C} 2$ were statistically significant, that is, there was a difference of $19.8 \%$, that is, the slope of the land was a factor that influenced this operation. Malinovski et al. (2006) complement that the greater the slope of the land, the greater the limitations of the self-propelled forest machine when moving, thus, the lower the productivity directly affecting the cost of production.

\section{CONCLUSIONS}

- The operational conditions to which the grapple saw is exposed affects the productivity of the work performed, with the median of effective productivity downhill being higher than the median of effective productivity uphill. - In the operational condition in which the machine obtains greater productivity per effective hour, the average energy efficiency is lower, therefore, the energy efficiency is inversely proportional.

- The production cost of processing is associated with the slope of the land, accordingly, the arrangements of the tree bundles must be planned with a view to providing better operational conditions for the grapple saw.

\section{REFERENCES}

ACKERMAN, P.; BELBO, H.; ELIASSON, L.; JONG, A.; LAZDINS, A.; LYONS, J. The COST model for calculation of forest operations costs. International Journal of Forest Engineering, London, v. 25, n. 1, p. 75$81,2014$.

ALAM, M.; ACUNA, M.; BROWN, M. Self-levelling feller-buncher productivity based on lidar-derived slope. Croatian Journal of Forest Engineering, Zagrib, v. 34, n. 2, p. 273-281, 2013.

ALAM, M.; WALSH, D.; STRANDGARD, M.; BROWN, M. A log-by-log productivity analysis of two Valmet 475EX harvesters. International Journal of Forest Engineering, London, v, 25, n.1, p. 14-22, 2014.

BANCO CENTRAL DO BRASIL. Conversão de moedas. Disponível em: <http://www4.bcb.gov.br/pec/conversao/conversao.asp> Acesso em: 05 jun. 2019. 
BEHJOU, F. K.; MAJNOUNAIN, B.; NAMIRANIAN, M.; DVORAK, J. Time study and skidding capacity of the wheeled skidder Timberjack 450C in Caspian forests. Journal Forest Science, Praga, v. 54, n. 4, p. 183-188, 2008.

BILICI, E.; AKAY, A.; ABBAS, D. Assessing the effects of site factors on the productivity of a feller buncher: a time and motion analysis. Journal of Forestry Research, Harbin, v. 30, p. 1471-1478, 2018.

BLAGOJEVIC, B.; JOHNSSON, R.; BJORHEDEN, R.; NORDSTROM, E.M.; LINDROOS, O. 2019: Multicriteria decision analysis (MCDA) in forest operations-an introductional review. Croatian Journal of Forest Engineering, Zagreb, v. 40, n. 1, p. 191-205, 2019.

CARMO, F. C. A.; FIEDLER, N. C., MINETTE, L. J.; SOUZA, A. P. Otimização do uso do trator florestal Forwarder em função da produtividade, custos e capacidade de carga, Revista Árvore, Viçosa, MG, v. 39, n. 3, p. 561-566, 2015.

CENTRO DE PESQUISAS METEOROLÓGICAS E CLIMÁTICAS APLICADAS À AGRICULTURA CEPAGRI. Clima dos municípios paulistas. Disponível em: <https://www.cpa.unicamp.br/outrasinformacoes/clima_muni_078.html> Acesso em: 16 out. 2019.

DIODATO, N.; BELLOCCHI, G. Spatial probability modelling of forest productivity indicator in Italy. Ecological Indicators, Amsterdan, v. 108, 2020.

FIEDLER, N. C.; ROCHA, E. B.; LOPES, E. S. Análise da produtividade de um sistema de colheita de árvores inteiras no norte do estado de Goiás. Floresta, Curitiba, v. 38, n. 4, p. 577-586, 2008.

HIESL, P.; BENJAMIN, J. G. Applicability of international harvesting equipament productivity studies in Maine, USA: A literature review. Forests, Basel, v. 4, n. 4, p. 898-921, 2013.

LOPES, S. E.; FERNANDES, H. C.; SANTOS, N. T.; RINALDI, P. C. N. Avaliação técnica e econômica de uma garra traçadora operando em diferentes produtividades. Scientia Forestalis, Piracicaba, v. 36, n. 79, p. 215-222, 2008.

MAGAGNOTTI, N.; PICCHI, G.; SPINELLI, R. A versatile machine system for salvaging small-scale forest windthrow. Biosystem Engineering, Londres, v. 115, p. 381-388, 2013.

MALINOVSKI, A.; MALINOVSKI, R. A.; MALINOVSKI, J. R. Análise das variáveis de influência na produtividade das máquinas de colheita de madeira em função das características físicas do terreno, do povoamento e do planejamento operacional florestal. Revista Floresta. Curitiba, v. 36, n. 2, p.169-182, 2006.

MIOT, H. A. Análise de correlação em estudos clínicos e experimentais. Jornal Vascuar Brasileiro, Porto Alegre, v. 17, n. 4, p. 275-279, 2018.

NASCIMENTO, A. C.; LEITE, A. M. P.; SOARES, T. S.; FREITAS, L. C. Avaliação técnica e econômica da colheita florestal com Feller-buncher. Revista Cerne, Lavras, v. 17, n. 1, p. 9-15, 2011.

R DEVELOPMENT CORE TEAM. R: A language and environment for statistical computing. reference index version 3.3.3. R Foundation for Statistical Computing, Vienna, Austria. ISBN 3-900051-07-0.

ROCHA, E. B.; FIEDLER, N. C.; ALVES, R. T.; LOPES, E. S.; GUIMARÃES, P. P.; PERONI, L. Produtividade e custos de um sistema de colheita de árvores inteiras. Cerne, Lavras, MG, v. 15, n. 3, p. 372-381, 2009.

SANTOS, H. G.; ALMEIDA, J. A.; OLIVEIRA, J. B.; LUMBRERAS, J. F.; ANJOS, L. H. C.; COELHO, M. R.; JACOMINE, P. K. T.; CUNHA, T. J. F.; OLIVEIRA, V. A. Sistema brasileiro de classificação de solos. Brasília: EMBRAPA, 5 ed. 2018, 353 p.

SCHETTINO, S.; MINETTE, L. J.; SOUZA, A. P. Correlação entre volumetria de florestas de eucalipto e produtividade e custos de máquinas de colheita de madeira. Árvore, Viçosa-MG, v. 39, n. 5, p. 935-942, 2015.

SPINELLI, R.; WARD, S. M.; OWENDE, P. M. A harvest and transport cost model for Eucalyptus spp. fastgrowing short rotation plantations. Biomass and Bioenergy, Oxford, v. 33, n. 9, p. 1265-1270, 2009.

SPINELli, R.; MAGAGNOTTI, N.; DI FUlviO, F.; BERGSTROM, D.; DANELON, M.; ALBERTI, G. Comparison of cost efficiency of mechanized fuel wood thinning systems for hardwood plantations on farmland. Croatian Journal of Forest Engineering, Zagreb, v. 35, p. 111-123, 2014.

STRANDGARD, M.; WALSH, D.; ACUNA, M. Estimating harvester productivity in Pinus radiate plantations using StandForD stem files. Scandinavian Journal of Forest Research, Stockholm, v. 28, n. 1, p. 73-80, 2013.

UNITED NATIONS ECONOMIC COMMISSION FOR EUROPE. $63^{\text {rd }}$ session. Fuel consumption for vehicle powered refrigeration units based on a conception of standard vehicle engine. INF.3, Geneva, Switzerland, 2007, 160 p. 